\title{
Influence of a Nozzle Type on the Thermal Performance of the Fill
}

\author{
Pavol Vitkovic \\ Czech Technical University in Prague \\ Technicka 4, Prague, Czech Republic \\ pavol.vitkovic@fs.cvut.cz
}

\begin{abstract}
The article shows the experimental investigation of a heat performance of the film fill. During the experiment was used two different spray nozzles with same water flow rate. Each spray nozzle created very different water distribution pattern. And this difference was investigating. The Merkel numbers are calculated for all measurement points. The Merkel number Me is a dimensionless number. This experimental study shows that the water distribution above the cooling fill could change the thermal performance of the cooling tower.
\end{abstract}

Keywords: cooling tower, heat exchanger, fill, nozzle

\section{Introduction}

This study presents an experimental investigation of the cooling tower. The cooling tower is mixed heat exchanger used in the industrial cooling. It is an evaporative heat rejection device, which takes out the low potential heat from a process to the atmosphere through the cooling of water by the ambient air. The cooling tower is consisting of 3 parts from heat and mass transfer view. The firs one is the spray zone. Its main task is distributing water over the fill zone. This one is consisting of the packing materials. It's creating the heat and mass transfer contact area between air and cooled water. And the last one is rain zone. It is creating by the packing materials. This study endeavours to understand the influence of water distribution over the packing material on the thermal performance of the fill. The film fill was used like packing materials with the height $300 \mathrm{~mm}$. Data from 2 different nozzles were analysed.

\section{Experimental Cell}

The experimental cell [1] is consisting of a counter flow cooling tower model, a water basin and a water channel (Fig. 1). The experimental test cell structure is made of aluminium profiles of square cross section $(1.48 \times 1.48 \mathrm{~m})$. The height of the test section is $5 \mathrm{~m}$. Side walls are made of a plastic material with polystyrene insulation. The test cell is designed as induced draft. The air flow is created by a centrifugal mid pressure fan.
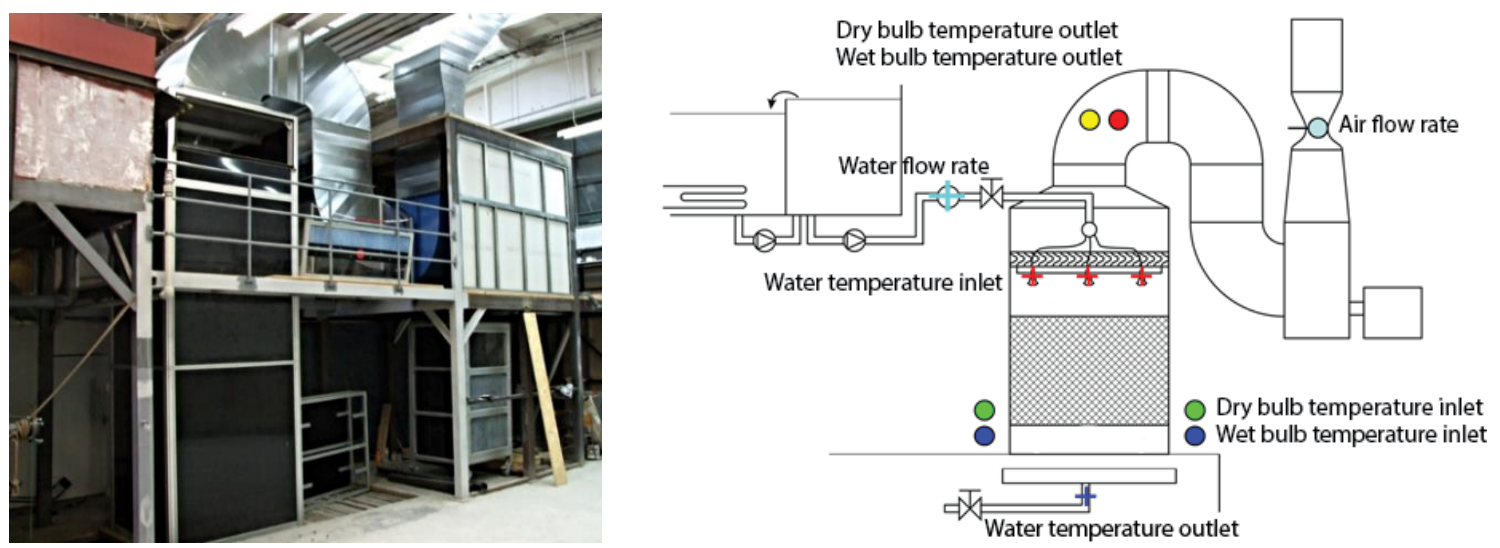

Fig. 1: Test cell in the laboratory. 
The cell and the fan are connected to an air vent system with cross section area $1 \mathrm{~m} 2$. The airflow through the fan is $54000 \mathrm{~m} 3 / \mathrm{h}$ at static pressure $160 \mathrm{~Pa}$. The RPM of the fan is controlled by a frequency converter. Hot water is delivered to the test cell by a PVC pipe from a hot water tank installed under the laboratory roof. The magnetic flow meter is built in this PVC pipe to measure and check the value of the water flow rate. Water pump built in the same PVC pipe to control the water flow rate. The air flow rate is calculated from static and total pressure in a contraction at the outlet from the system.

In the upper part of the experimental test, cell is placed the water distribution system with nozzles. The maximum number of nozzles is 5 . The arrangement of nozzles can be set in arbitrary geometry. For this experiment was arranged as shown in Fig. 2.

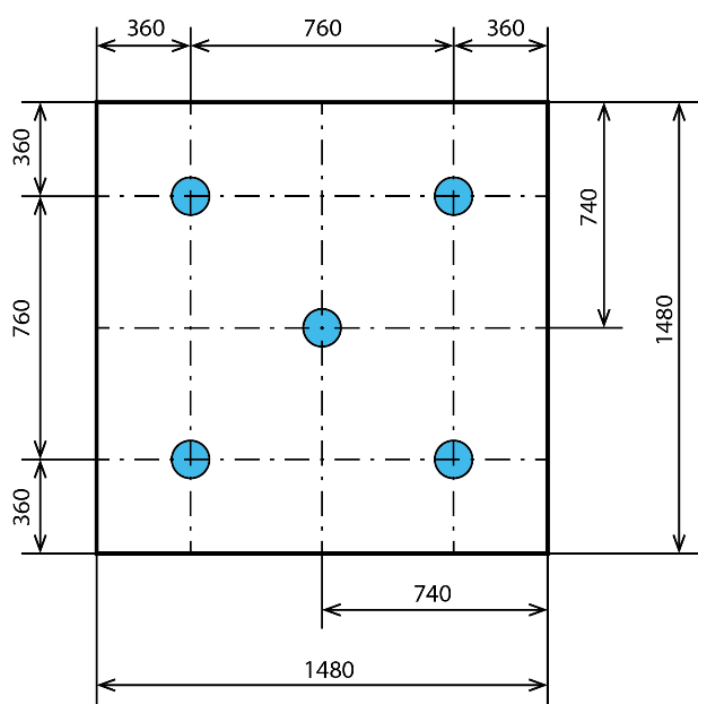

Fig. 2: Spray nozzles arrangement.

\section{Experimental Setup}

During the experiment was placed 6 and 4 layers of film fill into the test section of the experimental cell. The two different type of the spray nozzle was used. The first one is RT240 and second one is SFF (Fig. 3). These nozzles have very different water distribution characteristics.

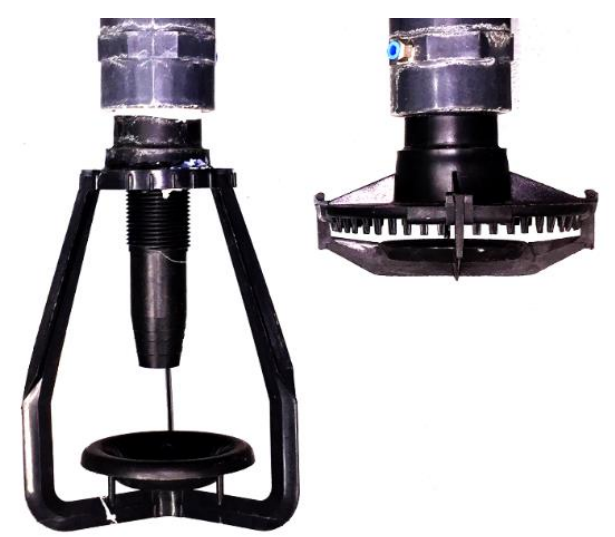

Fig. 3: Spray nozzle (RT240 - left; SFF - right).

\section{Results}

The water distribution of the nozzles was obtained by visualisation method [2]. A sample of water distribution both nozzles is shown in Fig. 4 and Fig. 5. The nozzle RT240 has the throw longer than nozzle SFF for same water flow rate. Data from the thermal measurement are shown in Tab. 1. 

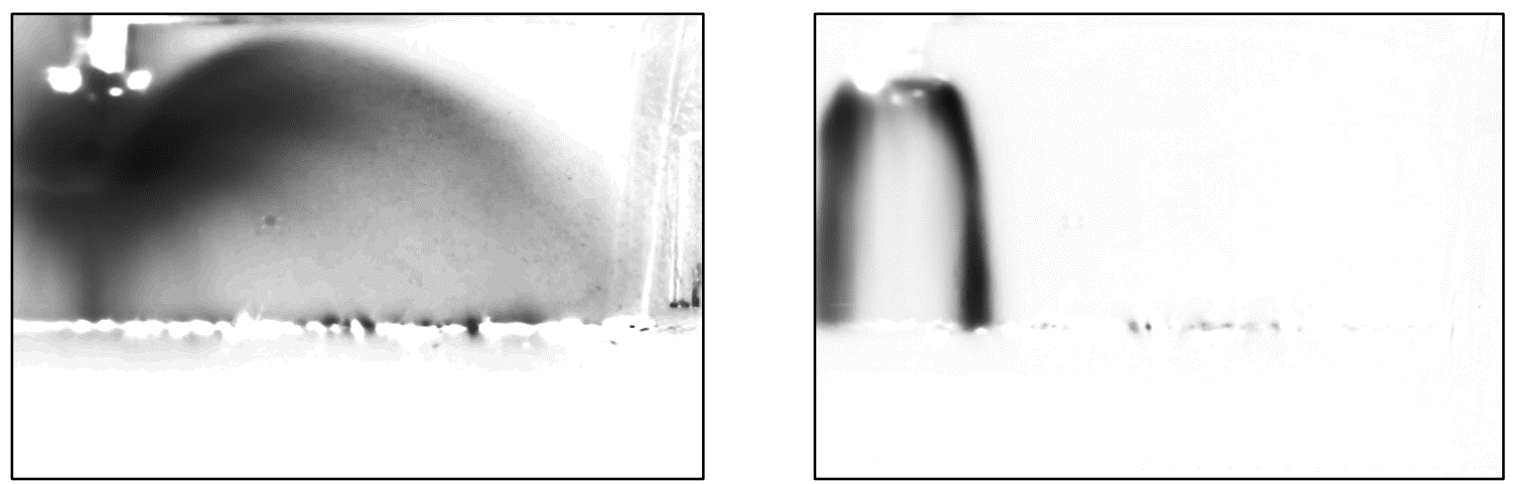

Fig. 4: Spray characteristics for mass water flow rate $1.4 \mathrm{~kg} / \mathrm{s}$ (RT240 - left; SFF - right).
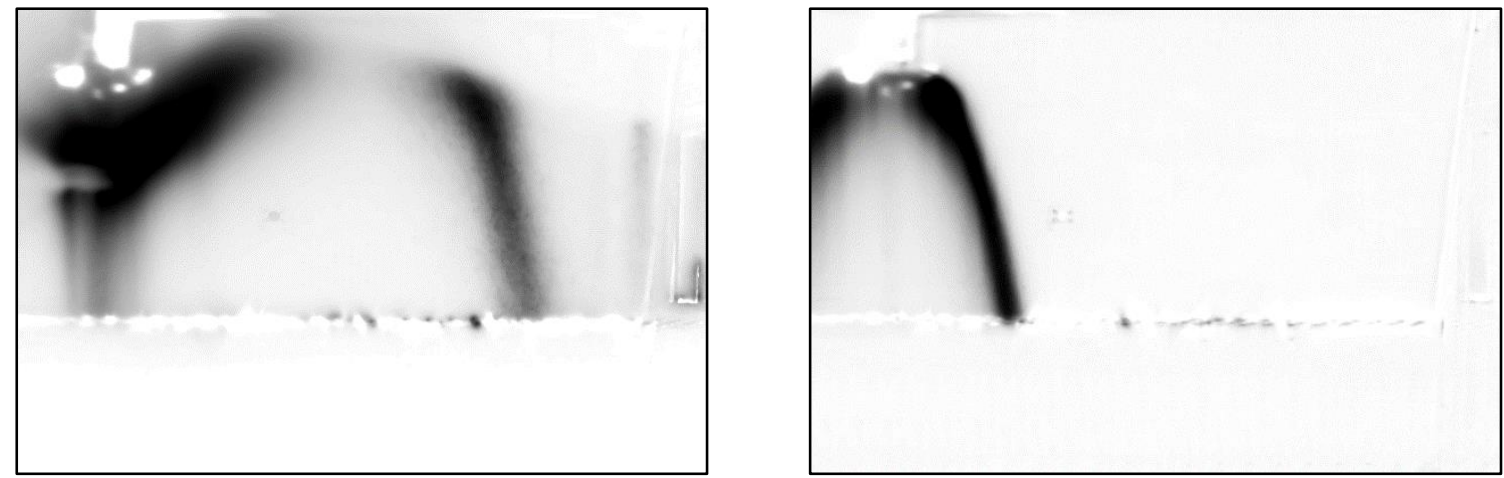

Fig. 5: Spray characteristics for mass water flow rate $2.0 \mathrm{~kg} / \mathrm{s}$ (RT240 - left; $\mathrm{SFF}$ - right).

Table 1: Important parameters of the experiment.

\begin{tabular}{|c|c|c|c|c|c|c|c|c|c|}
\hline & $\begin{array}{l}m A i r \\
{[\mathrm{~kg} / \mathrm{s}]}\end{array}$ & $\begin{array}{c}\text { tInAir } \\
{\left[{ }^{\circ} \mathrm{C}\right]}\end{array}$ & $\begin{array}{c}\text { tOutAir } \\
{\left[{ }^{\circ} \mathrm{C}\right]}\end{array}$ & $\begin{array}{c}\text { mWater } \\
{[\mathrm{kg} / \mathrm{s}]}\end{array}$ & $\begin{array}{c}\text { tInWater } \\
{\left[{ }^{\circ} \mathrm{C}\right]}\end{array}$ & $\begin{array}{c}\text { tOutWater } \\
{\left[{ }^{\circ} \mathrm{C}\right]}\end{array}$ & $L / G[-]$ & $M e[-]$ & $\operatorname{err}[-]$ \\
\hline \multirow{3}{*}{$\begin{array}{c}\text { RT240 } \\
1800 \mathrm{~mm} \\
\text { fill }\end{array}$} & 5,79 & 20,91 & 28,22 & 7,01 & 32,12 & 22,92 & 1,21 & 1,52 & 1,11 \\
\hline & 5,79 & 20,39 & 28,53 & 7,92 & 32,16 & 23,53 & 1,37 & 1,38 & 0,26 \\
\hline & 5,84 & 20,22 & 29,50 & 10,58 & 32,09 & 25,07 & 1,81 & 1,14 & $-1,61$ \\
\hline \multirow{3}{*}{$\begin{array}{l}\text { RT240 } \\
1200 \mathrm{~mm} \\
\quad \text { fill }\end{array}$} & 5,88 & 19,97 & 27,09 & 7,07 & 32,10 & 23,33 & 1,20 & 1,26 & 0,72 \\
\hline & 5,86 & 20,51 & 27,82 & 8,15 & 32,02 & 24,11 & 1,40 & 1,17 & 0,52 \\
\hline & 5,83 & 18,87 & 28,73 & 10,72 & 32,17 & 25,11 & 1,84 & 1,01 & 1,78 \\
\hline \multirow{3}{*}{$\begin{array}{c}\text { SFF } \\
1800 \mathrm{~mm} \\
\text { fill }\end{array}$} & 5,86 & 20,34 & 27,54 & 7,05 & 31,58 & 23,37 & 1,20 & 1,45 & 1,55 \\
\hline & 5,86 & 20,95 & 28,20 & 8,61 & 32,14 & 24,89 & 1,47 & 1,17 & 1,82 \\
\hline & 5,89 & 19,44 & 27,97 & 9,97 & 31,93 & 25,27 & 1,69 & 1,00 & 4,77 \\
\hline \multirow{3}{*}{$\begin{array}{c}\text { SFF } \\
1200 \mathrm{~mm} \\
\text { fill }\end{array}$} & 5,91 & 19,85 & 26,70 & 7,12 & 32,03 & 23,25 & 1,21 & 1,24 & 0,52 \\
\hline & 5,89 & 19,09 & 27,53 & 8,46 & 32,51 & 25,10 & 1,44 & 0,97 & 0,77 \\
\hline & 5,89 & 20,82 & 27,76 & 9,95 & 32,02 & 25,95 & 1,69 & 0,85 & 1,84 \\
\hline
\end{tabular}

The err is an error at heat balance, $m$ is mass flow rate, $t$ is temperature. For all measurement points are calculated the Merkel number Me [3]. The Merkel number $M e$ is defined by

$$
M e=\frac{K a V}{L}=c \int_{T_{2}}^{T_{1}} \frac{d T}{h_{s a}-h_{a}}
$$


where $K$ is mass transfer coefficient, $a$ is contact area, $V$ is active cooling volume, $L$ is water loading, $c$ is specific heat of water, $T_{l}$ is hot water temperature, $T_{2}$ is cold water temperature, $h_{a s}$ is enthalpy of air-water vapour mixture at bulk water temperature, $h_{a}$ is enthalpy of air-water vapour mixture at wet bulb temperature.

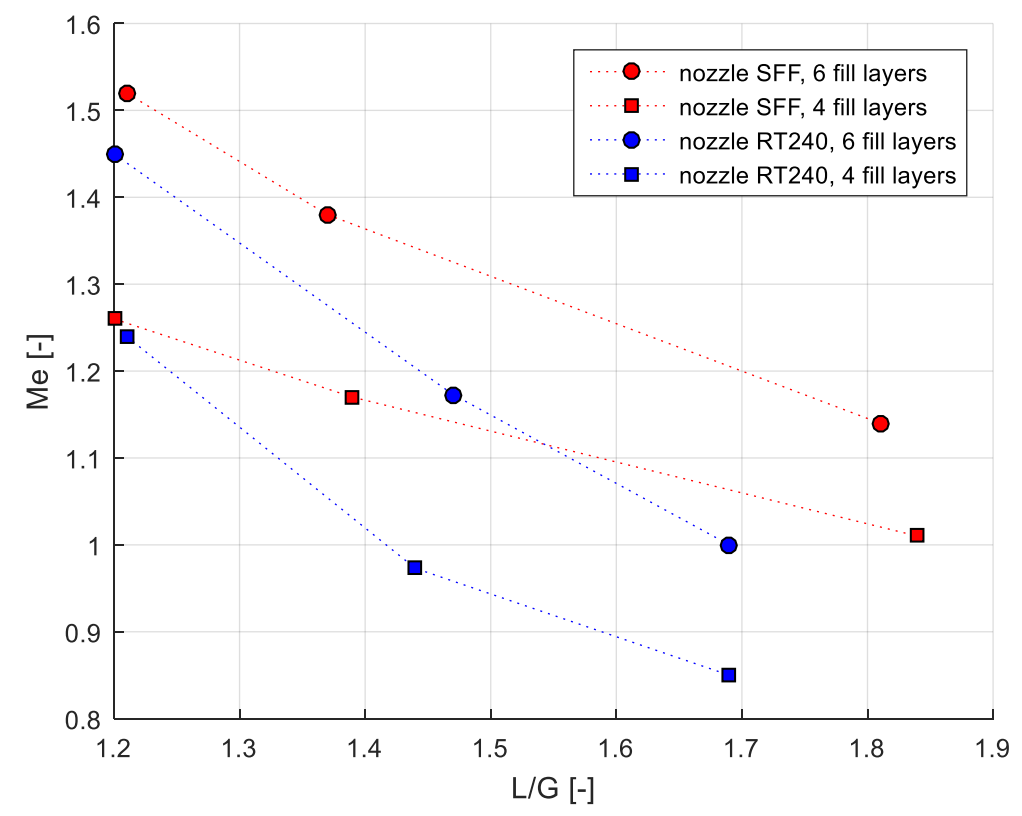

Fig. 1: The thermal performance of the fill - Merkel number vs. ratio L/G.

\section{Conclusion}

From the thermal data was calculated Merkel number Me. All measurement points are plotted in the graph Me vs. L/G. The results point to an interesting trend. The experimental study shows the very strong influence of the water distribution over the fill on the thermal performance of the cooling tower for higher ration $\mathrm{L} / \mathrm{G}$. However, differences are blurring with decreasing ration L/G. In this case, we have more air flow rate and it can break water structures from the nozzles.

\section{Acknowledgements}

This paper was compiled with the support of the Competence Centre - Advanced Technologies for Production of Heat and Electricity TE01020036 TA Czech Republic. and Centre of 3D volumetric velocimetry - COLA supported by the European Union (CZ.2.16/3.1.00/21569).

\section{References}

[1] L. Dvorak and J. Nozicka, "Counter-Flow Cooling Tower Test Cell," in EPJ Web of Conferences 67, DOI: 10.1051/epjconf/20146702024, 2014.

[2] P. Vitkovic, "Water Distribution Characteristics of Spray Nozzles in a Cooling Tower," in EPJ Web of Conferences 92. DOI: 10.1051/epjconf/20159202109, 2015.

[3] D. G. Kröger, "Air-cooled Heat Exchangers and Cooling Towers," Pennwell Corp., 2004. 